\title{
Environment Sustainability, Human Health and Media Function
}

\author{
Asghar Mirfardi ${ }^{1}$ \\ Yasouj University, I. R. of Iran
}

\begin{abstract}
There are new risks for human health, which, to some extent, can be explained by environment destruction and its consequences. Water supply problems, emerging new diseases, increasing existence diseases, decreasing life natural resources are clear consequences of environment destructions and environmental pollutions. This paper evaluated the functions of media in terms of Environment sustainability and human health. It aimed to study the function of media in the context of environment sustainability and human health. This study is done via documental method and existing resource (including archive and research reports about Environment sustainability and human health in the world). Increasing population, form one side, and decreasing natural resources, especially nonrenewable resources, from other side, going to terminate the human being opportunities for a better environment sustainability and better life, as well. Environment destruction is the second threatening factor for human life. Environment sustainability is so vital and useful for human life and human health. Environment destruction is the cause of 93 percentages of cancers, according American researchers studies. Keeping natural resources and environment biodiversity, from one side, and decreasing environment pollutions (air, water etc...), from other side, can help human being for a healthy and safe life. Mass media such as newspapers, magazines, radio, TV, web, etc... via offering news, reports and other programs declare the real situation of environment and its function for human health. Reviewing the situation of Environment sustainability and human health in the world societies, show that media have important functions in terms of environment sustainability: 1- Empowering human beings, via enlightening public thoughts about the importance of environment sustainability for human development and disadvantages of environment biodiversity destructions, as well. 2-Showing and introducing useful procedures for keeping environment biodiversity and sustainability. 3- Monitoring and criticizing public programs and policies, and also human behaviors about environment, media can help environment sustainability, which in its part, is a useful mechanism for human health. Thus, human health, as an important goal, can orient media activities to pro-environmental ones.
\end{abstract}

Key words: Environment sustainability, Human health, Media, Biodiversity, Sociology.

\section{Introduction}

There are new risks for human health, which, to some extent, can be explained by environment destruction and its consequences. Water supply problems, emerging new diseases, increasing existence diseases, decreasing life natural resources are clear consequences of environment destructions and environmental pollutions. Human being has a historical relationship to environment. Environment as main resource for living is important for sustainable development. In the past, human beings used to use environmental resources as raw materials and this kind of usage, were decreasing the natural resources. As population growth rate was low during past centuries, by such use method, environment had chance to be reproduced, naturally.

While various attempts have been made to link nature and society more closely together within environmental sociology, it now appears as though there is a general acceptance of rather traditional divisions between these two domains. Yet ecology specifies that natural and social entities are bound together in complex interrelations.

Environmental sociology from the past decades has been considered by sociologists and social scientists. Various papers and researches has been published during the past decades (Dunlap \& Catton, 1979, 1992/93; Buttel, 1987, 1996; Gramling \& Freudenburg, 1996). The modern world has been increasingly sensitized to "risk" as being "the organizing concept that gives meaning and direction to environmental regulation" (Jasanoff 1999:135). Different epistemological approaches have emerged for identifying and constructing risks, or managing uncertainty, in the modern world. Traditional quantitative assessments view "risk" as a calculable statistical determination of the probability of harm from a specific natural or human action. "Knowledge

1- Associate Prof. of Sociology and faculty member of Yasouj University (I R. of Iran). 
experts" operate within a clearly specified domain, utilizing a "rational actor theory" context for approaching risk (Freudenburg, 1988; Jasanoff, 1999; Clarke, 1999).

This paper evaluated the functions of media in terms of Environment sustainability and human health. It aimed to study the function of media in the context of environment sustainability and human health. It aimed to study the function of media in the context of environment sustainability and human health. This study is done via documental method and existing resource (including archive and research reports about Environment sustainability and human health in the world). Reviewing the theories and recent changes in environmental conditions has been done in this paper.

\section{Theoretical background}

There are several social theories that may be correspondent with environment and society. This paper is done with considering theories such as Parsons, social system theory, exchange theory, the social constructivist perspective on risk, Ecological modernization, and the actor-network theory. This later theory is an approach that, in significant respects, closely approximates a kind of 'ecological sociology'. Although it is best known for its controversial insistence on the agency of nonhumans, ANT is also associated with forceful critiques of conventional and critical sociology (Murdoch, 2001).

A broader view of risk emanates from sociology of knowledge perspective, viewing environmental policy as a socially-constructed issue, based on a continuing discourse among organizations which seeks to transform dissent into consent (Hannigan, 1995; Eder, 1999).

The social constructivist perspective on risk expands our concerns to understanding various cultural manifestations of the social and political interpretations of "risky ventures". This discursive response was created by modern technology because modern risks are "highly mediated risks, extremely open to social definition and interpretation" (Szerszynski, 1999: 240).

The two global theoretical models of post-industrial development have recently emerged that have direct relevance for environmental sociology. Ulrich Beck and Anthony Giddens have theoretical points in this subject. Beck in his theory identifies a shift in concern from the logic of Wealth distribution to a concern with the logic of the distribution of risk. This is the orienting characteristic of the modern world (Beck, 1992). Beck believe that social conflict and inequality will emerge from the distribution of technological risks which where created by the very successes of industrial society. These modern social threats differ from previous risks because: 1They are undectable by human sensory perception, 2- They transcend generations; and 3- They preclude causal attribution and compensation for victims (Beck, 1992; 1996). A second global model embraces "sustainable development" as the key issue for establishing harmonious relationships between economic development and environmental stewardship. "Ecological modernization", originally emerging out of the writings of Joseph Huber, Barry Commoner and Udo Simonis, sends a contradictory message to risk society theory with regard to the positive benefits of science and technology (Simonis, 1988; Commoner, 1990; Mol and Spaargarten, 1993). This theory appeared as a useful response to the failures of the initial wave of environmental management of the 1970s and early 1980s. Pollutants during these decades were speared, thus, industrial responsibility for "ecological harm" provided an irresolvable discourse on causality, impact and responsibility that resulted in, at best, ambiguous claims and counter-claims (Cohen, 1997). Cohen has summarized the theory of ecological modernization in terms of six general principles: correcting "the design flaws" of industrial technology through the process of "super industrialization", necessity of "strict government regulates", developing the "integrated pollution management" strategies reducing pollutants, the "organizational internalization of environmental responsibility" through the religious principle, and necessity of broader organizational network for decisionmaking in response to emerging ecological antagonisms and conflict over environmental policy(Cohen, 1997; 1998a; 1998b).

Ecological-symbolic theory emphasizes on the exchange relationships between human communities and their biophysical environment. This theory also identifies various elements of the social constructivist framework by viewing continuous claims-making and litigation as part of a "corrosive community" response to the failure of traditional institutional support systems for diagnosis and compensation of damages from contamination(Picou, 1999). 
Resource-dependency theory focuses on cultural and economic linkages, rather than lifescape assumptions. As such, traditional knowledge of indigenous subsistence cultures provides an alternative discourse narrative. Such a consideration broadens resource management concerns to include elements of traditional culture within the framework of impact assessment (Picou, 1999).

Theory of Inglehart (1997) in terms of value orientation, can related to resource management and environmental protection systems. Inglehart's theory of social change is based upon value change, particularly inter-generational value change (Inglehart 1977). This theory has two basic hypotheses: 1-A Scarcity hypothesis: An individual's priorities reflect the socioeconomic environment. 2-A Socialization hypothesis: The relationship between socioeconomic environment and value priorities is not one of immediate adjustment. A substantial time lag is involved because, to a large extent, one's basic values reflect the conditions that prevailed during one's pre-adult years (Inglehart, 1997: 33).

Actor-network theory (ANT) was developed by two leading French Science and Technology Studies (STS) scholars, Michel Callon and Bruno Latour, the British sociologist John Law, and others.

Actor-network theory is 'co-constructionist': it seeks to identify how relations and entities come into being together.

Actor-network theory (ANT) declares that the world is full of hybrid entities (Latour, 1993) containing both human and non-human elements, and was developed to analyze situations where separation of these elements is difficult (Callon 1997: 3). ANT deals with the

Social-technical divide by denying that purely technical or purely social relations are possible. ANT considers both social and technical determinism to be flawed and proposes instead a socio-technical account (Latour 1986; Law and Callon, 1988) in which neither social nor technical positions is privileged. Latour (1991:117) argues that: "Contrary to the claims of those who want to hold either the state of technology or that of society constant, it is possible to consider a path of an innovation in which all the actors co-evolve."

To address the need to treat both human and non-human actors fairly and in the same way, ANT is based upon three principles: agnosticism, generalized symmetry and free association (Callon, 1986). The first of these tenets, agnosticism, means that analytical impartiality is demanded towards all the actors involved in the project under consideration, whether they are human or non-human. Generalized symmetry offers to explain the conflicting viewpoints of different actors in the same terms by use of an abstract and neutral vocabulary that works the same way for human and non-human actors. Neither the social nor the technical elements in these 'heterogeneous networks' (Law 1987) should then be given any special explanatory status. Finally, the principle of free association requires the elimination and abandonment of all a priori distinctions between the technological or natural, and the social (Callon, 1986; Singleton and Michael, 1993).

In summary, under the principles of agnosticism, generalized symmetry and free association actor-network theory attempts impartiality towards all actors in consideration, whether human or non-human, and makes no distinction in approach between the social, the natural and the technological situations.

Parsons (1951), in his theory of social system, considered the social system as four sub-systems (social, economic, cultural and social sub-systems).

\section{Environment, human life and socio-economic changes}

The industrial revolution has affected the socio-economic and cultural structures of many societies. Some sociologists (Weber, 1958) have considered the cultural and religious contexts as rational reason for economic changes in western countries. Cultural and value conditions and consequences of development are the most critical matters in development studies.

As Parsons (1951) indicated the Social system is a regular combination of four sub-systems. Every change in each sub-system would affect the whole of system. Environmental and cultural sub-systems are the elements of such social system.

Culture, in its specific meaning, includes all subjective parts of human beings, beliefs, attitudes, values, customs, etc ...that are known as cultural dimensions of human life. 
The UN World Commission on culture and development, recognized the cultural dimensions of environmental management should be considered in relation to indigenous knowledge, the built environment, urban culture, population growth, poverty, economic growth, and biosphere, sustainability, and cultural diversity (Arizpe, 2004: 179).

Although culture have most important role in societies, in compare with the other big issues of developmentsuch as the impoverishments of certain population groups because of resettlement or development failures, or the violation of human rights, or the decimation of valued environments- culture seems a rather minor issue, a luxury to be dealt with after issues are worked out (Alkire, 2004: 207).

Increasing the people participation in the environment protection programs is depended to education and developing cultural awareness in the society. This duty, at most, for the socialization institutions such as family, education organizations, and other cultural institutions and organizations.

\section{Conclusion and discussion}

Sociology and environment as correlated subjects of human life have appeared the new area of science. This new science has its importance and necessity. Environmental protection programs, at first step, need cultural condition and social empowerment.

Increasing population, form one side, and decreasing natural resources, especially nonrenewable resources, from other side, going to terminate the human being opportunities for a better environment sustainability and better life, as well. Environment destruction is the second threatening factor for human life. Environment sustainability is so vital and useful for human life and human health. Environment destruction is the cause of 93 percentages of cancers, according American researchers studies. Keeping natural resources and environment biodiversity, from one side, and decreasing environment pollutions (air, water etc...), from other side, can help human being for a healthy and safe life. Mass media such as newspapers, magazines, radio, TV, web, etc... via offering news, reports and other programs declare the real situation of environment and its function for human health. Reviewing the situation of Environment sustainability and human health in the world societies, show that media have important functions in terms of environment sustainability: 1- Empowering human beings, via enlightening public thoughts about the importance of environment sustainability for human development and disadvantages of environment biodiversity destructions, as well. 2-Showing and introducing useful procedures for keeping environment biodiversity and sustainability. 3- Monitoring and criticizing public programs and policies, and also human behaviors about environment, media can help environment sustainability, which in its part, is a useful mechanism for human health. Thus, human health, as an important goal, can orient media activities to pro-environmental ones.

\section{References}

[1] Alkire, Sabina (2004). "Culture, poverty, and external intervention", ", in Rao Vijayendra and Walton Michael (edits.) (2004). Culture and Public Action. Stanford (California: Stanford University Press. pp: 163-184.

[2] Arizpe, Lourdes (2004). "The Intellectual History of culture and development institutions", in Rao Vijayendra and Walton Michael (edits.) (2004). Culture and Public Action. Stanford (California: Stanford University Press. pp: 185209.

[3] Beck, U. (1992). Risk Society: Toward a New Modernity. London: Sage.

[4] Beck, U. (1996). " Risk Society and the Provident State", pp. 27-43 in S. Lash; B. Szerszynski and B. Wynne (eds.). Risk, Environment and Modernity: Towards a New Ecology. London: Sage.

[5] Buttel, Frederick H. (1987). "New Directions in Environmental Sociology." Annual Review of Sociology 13:465488.

http://dx.doi.org/10.1146/annurev.so.13.080187.002341

[6] Buttel, Frederick H. (1996). "Environmental and Resource Sociology: Theoretical Issues and Opportunities for Synthesis." Rural Sociology 61:56-76.

http://dx.doi.org/10.1111/j.1549-0831.1996.tb00610.x

[7] Callon, M. (1986). 'Some Elements of a Sociology of Translation: Domestication of the Scallops and the Fishermen of St Brieuc Bay'. Power, Action \& Belief. A New Sociology of Knowledge? Law, J. (Ed). Routledge \& Kegan Paul, London: 196-229. 
[8] Callon, M. (1997). 'Actor-Network Theory - The Market Test (draft)' Actor Network and After Workshop. Centre for Social Theory and Technology (CSTT), Keele University, UK http://www.keele.ac.uk/depts/stt/stt/ant/callon.htm, 31 July 1997.

[9] Clarke, L. 1999. Mission Improbable: Using Fantasy Documents to Tame Disaster. Chicago: University of Chicago Press.

[10] Cohen, M. J. (1997). "Risk society and sociological modernization: Alternative Visions for post-industrial nations." Futures 29(2): 105-119. http://dx.doi.org/10.1016/S0016-3287(96)00071-7

[11] Cohen, M. J. (1998a). "Science and environment: Assessing cultural capacity for ecological modernization." Public Understanding of Science 7(2): 149-167. http://dx.doi.org/10.1088/0963-6625/7/2/004

[12] Cohen, M. J. (1998b). "Sustainable Development and Ecological Modernization: National capacity for rigorous Environmental reform." In D. Reqeuir-Desjardins, C. Splash and J Van Der Straaten(eds.), Environmental Politics and Societal Aims. Dordrecht: Kluwer Press.

[13] Commoner, B. (1990). Making Peace with the Planet. New York: Pantheon.

[14] Dunlap, Riley E. and William R. Catton, Jr. (1979). "Environmental Sociology." Annual Review of Sociology 5:243273.

http://dx.doi.org/10.1146/annurev.so.05.080179.001331

[15] Dunlap, Riley E. and William R. Catton, Jr. (1992/93). "Toward an Ecological Sociology: The Development, Current Status, and Probable Future of Environmental Sociology." The Annals of the International Institute of Sociology, 3:263-284.

[16]Eder, K. (1999). "Taming Risks through Dialogues: The Rationality and Functionality of Discoursive Institutions in Risk Society", pp. 225-248 in M. J. Cohen (edit.). Risk in The Modern Age. London: McMillan.

[17]Freudenburg, W. R. 1988. "Perceived Risk, Real Risk: Social Science and the Art of Probabalistic Risk Assessment." Science, 7: 44-49.

http://dx.doi.org/10.1126/science.3175635

[18] Gramling, Robert and William R. Freudenburg. "Environmental Sociology: Toward a Paradigm for the 21st Century." Sociological Spectrum 16:347-370.

http://dx.doi.org/10.1080/02732173.1996.9982141

[19] Hannigan, J. (1995). Environmental Sociology: A Social Constructionist Perspective. London: Routledge.

[20] Inglehart, Ronald (1977). The Silent Revolution. Princeton: Princeton University Press.

[21] Inglehart, Ronald (1997). Modernization and Postmodernization: Cultural, Economic and Political Change in 43 Societies. Princeton: Princeton University Press.

[22] Jasanoff, S. 1999. “The Songlines of Risk.” Environmental Values 8:135-152. http://dx.doi.org/10.3197/096327199129341761

[23] Latour, B. (1986). 'The Powers of Association'. Power, Action and Belief. A new sociology of knowledge? Sociological Review monograph 32. Law, J. (Ed). Routledge \& Kegan Paul, London: 264-280.

[24] Latour, B. (1991). 'Technology is society made durable'. A Sociology of Monsters. Essays on Power, Technology and Domination. Law, J. (Ed). Routledge, London: 103-131..

[25] Latour, B. (1993). We have never been modern. Harvester Wheatsheaf, Hemel Hempstead.

[26] Law, J. (1987). 'Technology and Heterogeneous Engineering: The Case of Portuguese Expansion'. The Social Construction of Technological Systems: New Directions in theSociology and History of Technology. Bijker, W. E., Hughes, T. P. and Pinch, T. J. (Eds). MIT Press, Cambridge, Ma: 111-134.

[27] Law, J. and Callon, M. (1988). 'Engineering and Sociology in a Military Aircraft Project: A Network Analysis of Technological Change'. Social Problems 35(3): 284-297.

http://dx.doi.org/10.1525/sp.1988.35.3.03a00060

[28] Mol, A. and G. Spaargaren (1993). "Environment, Modernity and the Risk Society: The Apocalyptic horizon of Environmental Reform." International Sociology, Vol. 8, No. 4, pp. 431-459.

http://dx.doi.org/10.1177/026858093008004003

[29] Murdoch, Jonathan (2001). "Ecologising Sociology: Actor- Network Theory, Co-construction and the Problem of Human Exemptionalism", (2001), 35: 111-133 Cambridge Journals Online, Cambridge University Press.

[30] Parsons, T. (1951). The Social System. New York: Free Press. 
[31] Picou, J. Steven (1999). "Theoretical Trends in Environmental sociology: Implications for resource management in the modern world." Social and Economic Planning Conference, Minerals Management Service, August 24-26, 1999, Park City, Utah

[32] Simonis, U. (1988). Beyond Growth: Elements of Sustainable Development. Berlin: Edition Sigma.

[33] Singleton, V. and Michael, M. (1993). 'Actor-Networks and Ambivalence: General Practitioners in the UK Cervical Screening Programme'. Social Studies of Science 23: 227-264.

http://dx.doi.org/10.1177/030631293023002001

[34] Szerszynski, B. (1999). "Risk and trust: The perfomative dimension", Environmental Contaminents. Lexington, MA: D.C. Heath.

http://dx.doi.org/10.3197/096327199129341815 